\title{
Learning through Personal Development at the Hong Kong Institute for Vocational Education
}

\author{
Anita Sui Man Leung \\ Department of Business Administration \\ Hong Kong Institute of Vocational Education (Tsing Yi) \\ 20 Tsing Yi Road, NT, Hong Kong \\ Tel: 852-3757-9225 E-mail: asmleung@vtc.edu.hk
}

Accepted: December 06, 2012 Published: January 24, 2013

Doi:10.5296/ijld.v3i1.3126

URL: http://dx.doi.org/10.5296/ijld.v3i1.3126

\begin{abstract}
A new "3+3+4" education system was proposed by the Hong Kong Special Administrative Region (HKSAR) Education and Manpower Bureau in 2000. This new education system, implemented in 2009, seeks to offer to all students the opportunity to gain a fully rounded education. To adapt to these changes, vocational and lifelong education now place greater emphasis on the employability skills and all-round development of individuals. Personal development is the cornerstone of lifelong learning and academic and professional achievement. The challenge for educators is to formulate effective personal development strategies and education by developing different learning methodologies to strengthen students in learning and development. Moreover, experiential and lifelong learning need to be emphasised. All methodologies should be adopted with significant learning approaches. Enquiry-based, peer-assisted and active learning can support students over the learning journey both inside and outside the classroom.

This chapter undertakes an in depth critical review of the literature related to the issues of learning and personal development. Data was collected from multiple sources, including questionnaires and interviews, and involved the differing perspectives of students, educators and human resource practitioners to explore the personal development opportunities of students at the Hong Kong Institute for Vocational Education. The author identified the key issues in learning, developed a practical guide to personal development for educators and formulated an active learning model to support personal development. This study drew heavily on research experience to identify pathways to personal development such as a Supplemental Instruction Programme at a Hong Kong institution. Through this work, important insights into informal learning were achieved and practical guides and innovative learning strategies were developed to support personal development education.
\end{abstract}

Keywords: Active learning, Informal learning, Personal development, Supplemental Instruction, Peer-Assisted Learning and Vocational Education 


\section{INTRODUCTION}

As part of the wider Hong Kong educational reforms aimed at promoting success in the global knowledge economy (Education Commission 2000), the system of vocational education and training is undergoing radical reform in the territory. To meet these new challenges, the introduction of a new structure, namely " $3+3+4$ ", to secondary and higher education in 2009 will require post-secondary level vocational programmes to respond. The 3 years Higher Diploma programme is shorten to two years programme for learners to take. In addition, The Education Commission also recommends the provision of "a broad senior curriculum to enable students to acquire experiences in various key learning areas, construct a broad knowledge base and enhance their ability to analyse problems". (Education Commission 2000, p.100). Due to shorten of learning journey to 2 years, formal learning conducted in class is no longer enough to enable every person to attain all-round development. Consequently, informal learning should be explored in systematical ways. This should be a challenge for educators or practitioners to develop education to support people in all-round development and enrich life experience. In this regard, the author conducted a relevant research to examine personal development opportunities at the pilot institute in Hong Kong.

\section{PURPOSE OF THE STUDY}

- To examine personal development opportunities at the Hong Kong Institute for Vocational Education

- Identify an effective learning model to strengthen student in learning and development

\section{METHODS}

Literature review in the issues of learning and personal development was conducted. In addition, full-time students registered at the Higher Diploma level offered at the pilot institute in Hong Kong were surveyed. A total of 146 structured questionnaires containing predetermined questions were delivered to students directly, eliciting 134 responses. Furthermore, eight educators were invited and six semi-structured interviews were conducted. Ten sub-questions were used to guide this process. Six human resource practitioners were invited to attend interview with six further sub-questions designed to guide this inquiry and enhance the validity of data collected from the survey research and to explore further ideas to draw up common themes for the study.

\section{MEANING OF LEARNING}

What does learning mean? Joy-Matthews (2004) describe how the process of learning links 'outcome and processes'. Intended outcomes are individual goals; achieved outcomes lead to increased capabilities. Michael \& Modell (2003) address learning as changes in behaviour and cooperative learning models involving the student, peers and teachers to facilitate learning. Kolb \& Fry (1995) discuss experiential learning in formal and informal setting through reflection. (Kolb \& Fry, 1975 retrieved from infed). 
Although Kolb has developed more than one account of experiential learning over his career, pertinent here is the notion of experiential learning that explores and applies knowledge, and learning processes and skills in an immediate and relevant setting. This sort of learning is supported by a college or institute rather than being simply an informal process.

Kolb \& Fry suggest that learners and learning can begin at any point of the learning cycle (see Figure 1).

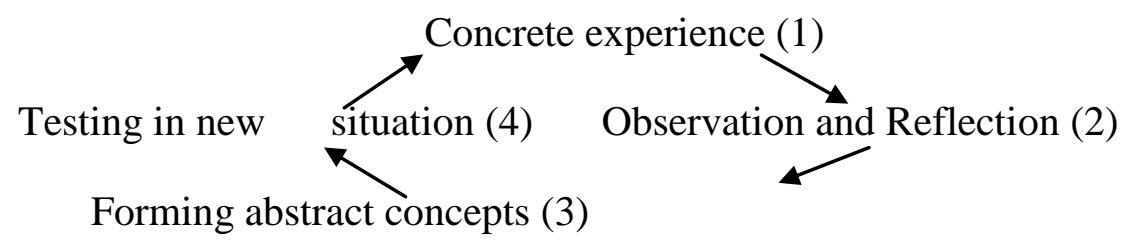

Figure 1: Kolb and Fry learning cycle (Source: infed online resources: http://www.infed.org/biblio/b-explrn.htm)

Kolb and Fry argue that institutions need to ascertain where learners are at in the cycle and then intervene to support learning. Joyce and Calhoun (1996) describe how learning experiences are composed of content, process and social climate. (Joyce and Calhoun 1996, p.xi). Zimmerman et al. (1996) argue self-regulated learning is not something that can be done for students, it is something that is done by them (Zimmerman et al. 1996, p.22).

Summarising all the selected literature, learning has the following meanings: linking outcome and process (Joy-Matthews 2004); learning is a change in behaviour (Michael and Modell 2003); learning in formal and informal setting, through reflection (Kolb and Fry 1975); learning is composed of content, process and social climate (Joyce and Calhoun 1996) and self-regulated learning is done by students (Zimmerman et al. 1996).

\section{PERSONAL DEVELOPMENT EDUCATION}

How can learning apply to personal development? Sanford (1969) argues that learning is essentially about whole individual development as the individual interacts with their environment. Thus, education is about promoting this process.

He outlines some key elements of personal development:

Personal development involves "the organisation of increasing complexity", and thus is distinct from simple notions of "change" or "growth".

It involves the whole individual and their development: the intellect, emotions, and action are all inseparable and in interaction.

It is progressive: a succession of developmental changes takes place. 
It reflects an interaction between the person and the environment.

(cited in Hofer \& Pintrich, 2002, p.26)

Cotton (1995) notes how learning, competency and skills can become a part of personality and learners who achieve skills, competency and knowledge will incorporate this learning into their self-image. Personality is described by Cotton as "the characteristic patterns of behaviour, thought and emotion which determine the way a person adjusts to the environment" (Cotton, 1995, p.13).

Patterson (2005) presents the student development equation $\mathrm{B}=\mathrm{f}(\mathrm{PxE})$ at the Canadian Institute of Student Affairs and Services to explore how behaviour (learning) is related to the way people interact with their environment (Nifakis and Barlow, 2007, p.3).

Stevenson (2003) notes that "meta-cognition performs the function of organising, selecting and monitoring cognitive activity". (Campione et al. 1989; Jausovec 1994 cited in Stevenson 2003, p.173). With full support, students can become autonomous learners, regulating and developing their skills through reflection to develop into creative problem-solvers.

Noll (2009) argue that "learners control their learning and construct their new understandings through active engagement with the past and present experience through constructive approach".(Noll Wm., 2009, p. 48-49). This approach can be adopted appropriately when the institution builds a sustainable constructive classroom culture and through major changes in curriculum, scheduling and assessment.

Guillaume, Yopp and Yopp (2007, p.3) argue that active learning for personal development requires active teaching:

Active teaching is an approach to instruction vigorously pursued by the teacher with the full intention to improve student learning and student control over that learning. Active teaching is characterized by clear purposes and is based on what the teacher knows about her particular students and about human learning and motivation. Active teachers modify instruction based on learners' reactions and mastery of new information and manage their classrooms to maximize student success.

Cotton (1995), Stern and Huber (1997), and Kember (2008) also emphasise active learning. Cotton suggests that through the use of learning support groups, individuals find assistance and encouragement as they work with others on the same learning tasks.

Michael and Modell discuss the provision of resources and the key role of the educator in developing new learning experiences: 
The successful instructor must be psychic, anticipating every possible problem that students may have and preparing suitable learning experiences to address each of these problem....they must develop appropriate activities, along with supporting resource material, to meet all of these potential needs. Preparing for class must also include anticipating the unknown, an impossible task, and having solutions at hand for unknown problems... The questions that must be kept in mind are, "What problems do I anticipate my students will have when working with pertinent information?" and "What resources do I need to help the students recognize the problems they are having?"

\section{Development of generic skills}

The Education Bureau has developed personal development training to develop the generic skills necessary for lifelong learning. The learning processes involved in co-curricular activities help students raise questions after reflection, or through communication and collaboration with others, and find solutions using their own initiative (Education Manpower Bureau 2004, p.4). Extracurricular activities are vital to

help develop generic skills such as communication and interpersonal skills, and problems solving techniques through participation.

Kember (2008) also notes that generic capabilities are nurtured if programmes and the curriculum provide learning activities which require the deployment of the capability in question. (Kember, 2008, p.15).

Edwards, Hanson and Raggatt (1996, p.261) note that personal skills offer a common strand linking learning experiences through school, further and higher education. Individuals pursue different specialisations as they move between education, training, and work. In this area of transfer - the skills required for transfer - links can be made between stakeholders promoting work related skills, and those that promote learning skills.

Murdock and Scutt (2003) outlined the Personal Competency Model to develop effective management skills, widely used in United Kingdom as outlined below:

\begin{tabular}{|l|l|}
\hline \multicolumn{1}{|c|}{ Behavioural Indicator } & \multicolumn{1}{|c|}{ Sub-indicators } \\
\hline Acting assertively & - \\
\hline Acting strategically & - \\
\hline Behaving ethically & - \\
\hline Building teams & Managing and relating to others \\
\hline Communicating & - \\
\hline Focusing on results & $\begin{array}{l}\text { Planning and prioritizing, striving for } \\
\text { excellence }\end{array}$ \\
\hline Influencing others & - \\
\hline Managing self & $\begin{array}{l}\text { Controlling emotions and stress } \\
\text { Managing personal learning and } \\
\text { development }\end{array}$ \\
\hline Searching for information & - \\
\hline
\end{tabular}




\begin{tabular}{|l|ll|}
\hline $\begin{array}{l}\text { Thinking and } \\
\text { decision-making }\end{array} \quad \begin{array}{l}\text { Analysing, conceptualizing, taking } \\
\text { decisions }\end{array}$ \\
\hline
\end{tabular}

Table 1: Overview of the Personal Competency Model (Source: Murdock and Scutt 2003, p.xxix)

\section{Development of attitudes and values}

Again, as outlined by the Education Bureau, personal development is closely related to students' attitudes and ability to cope with the future change. These attitudes and values can be developed gradually through active participation in learning. The Bureau has proposed a set of values and attitudes in personal development, for inclusion in the school curriculum. They are as follows:

Core Values: sanctity of life, truth, aesthetics, honesty, human dignity, rationality, creativity, courage, liberty, affectivity, individuality.

Sustaining Values: self-esteem, self-reflection, self-discipline, self-cultivation, principled morality, self-determination, openness, independence, enterprise, integrity, simplicity, sensitivity, modesty and perseverance.

Attitudes: optimism, participation, criticism, creativity, appreciation, empathy, caring and concerned, positive, confidence, cooperation, responsibility, adaptability, open-mindedness, respectful, a desire to learn, diligence, commitment to core and sustaining values.

(Education and Manpower Bureau 2004, p.15)

As suggested by Cotton (1995, p.91-94), attitudes are influenced by everything which happens to us, personal values, and the values and norms of society. He also suggests permanent changes of attitude are linked to self-image and self-esteem. Therefore, educators have to consider the best way to assist students to build up their own good attitudes and values in life.

\section{Personal development through individual exploration}

According to Murdock and Scutt (2003, p.xxviii), personal competency can be achieved through self-development so as to explore personal strengths and weaknesses and learn how to overcome this. This will provide learners with the opportunity to agree with others on how to address their own self-development needs, through formal reviews, daily interaction and informal feedback, advice and guidance.

Johns (1996, p.84) discusses how learning to reflect is key in increasing self-awareness and personal development. Johns also suggests that the training method adopted in personal development through individual exploration should be a developmental and evolving list called a 'self-planned learning' list, describing the major tasks completed and major personal changes achieved during learning process. 
As cited in Cotton (1995, p.111), Carl Rogers notes that the teacher must facilitate the development of the individual's self-concept, and help individual student to achieve self-actualisation. In order to achieve this, both the teacher and the student must strive to be self-aware. When the self-image and the ideal self are closely related, then the person is well-adjusted, able to participate in effective in learning and is positive about life.

\section{Competency-based learning}

Sumerall, Lopez and Oehlert (2000, p.5) discuss how an expert is needed to set appropriate competencies. Competencies should be contained and practical, and based on the advice of established experts who can review competencies within the context of change. They design competency standards in accordance with functional areas, such as accounting competencies designed for the Higher Diploma course in Accounting. When setting these standards, the designer should identify special tasks in accordance with functional areas and design simulated activities to engender familiarity with particular professions. According to Arter (2001, p.83), the design should improve as well as judge students' performance, as follows:

1. The performance target should be clear and unaltered, providing an instructional target for the teacher and a learning target for the students.

2. There should be no "mystery" regarding performance expectations and the criteria by which students' work will be judged.

3. The work samples equip students to more accurately self-assess and improve their work.

Performance standards should be set and feedback relating to strengths and weaknesses provided so students know whether they have achieved the required competencies. Sumerall, Lopez and Oehlert (2000) discusses competency-based education and training in professional psychology as having the following nine competency areas:

\begin{tabular}{ll}
\hline- & Training in basic psychological knowledge \\
- & Training in relationship building \\
- & Training in assessment \\
- & Training in intervention \\
- & Training in research \\
- & $\quad$ Training in in supervision \\
- & Training in advanced clinical skills \\
& Tran ethics and attitudes
\end{tabular}

(Sumerall, Lopez and Oehlert 2000, p.13-15)

All above training modules are tasks-oriented and are related to the duties required in the workplace. This supports ideas explored in Fletcher's (2000) qualification-drive 
competence-based systems. Teaching strategies discussed by Sumerall et al.(2000), including qualification-driven competency-based systems (comprising demonstration, evaluation, feedback sessions, lectures, role models and practice exercises), can also be adopted.

\section{The Active Learning Model}

Active teaching helps students to learn actively as noted by Guillaume, Yopp and Yopp (2007). Guillaume et al. (2007) argue teachers can motivate students through understanding them, setting clear goals and using appropriate teaching methods to help students to learn effectively. Stern and Huber (1997, p.19) offer further explanation:

Active learning is defined in one sense to mean that the learner uses opportunities to decide about aspects of the learning process. A second definition of active learning connects it to mental activity in another sense: it refers to the extent to which the learner is challenged to use his or her mental abilities while learning. Thus active learning on the one hand has to do with decisions about learning and on the other hand making active use of thinking.

Cotton (1995, p.42) reinforce Stern and Hubers' notion of active learning, outlining that active learning is a popular strategy in teaching and training. She also suggests that in learning support groups, individuals find assistance and encouragement as they work with others on the same learning tasks. Kember (2008, p.10) discusses higher-order teaching, including active learning thus:

One of the most important facets of the teaching and learning environment for promoting the development of capabilities was the provision of active learning experiences. Practise of the capabilities occurred when there was an activity which demanded their application.

Active learning methods discussed in this study encourage students to make decisions about their learning strategies, within the context of support groups and resources that support experiential learning. The active learning model can comprise action learning, enquiry-based learning, project-based learning, flexible learning, and collaborative learning, constructivism in learning, meta-cognition, self-regulated learning, problem-based learning, peer-assisted learning, experiential learning and lifelong learning. These methods

enrich the learning experience, and should be adopted in formal curriculum. They can also include extra-curricular activities so as to strengthen personal development.

\section{RESULTS}

Views regarding teaching and learning methodology and personal development curriculum were collected from students, educators and human resource practitioners during the research period (December 2005 to July 2006). 


\section{Views of students}

In the quantitative research phase, full-time students at the pilot institution were surveyed. A total of 146 structured questionnaires containing predetermined questions were delivered to students directly, eliciting 134 responses. These questionnaires were distributed to seven representative groups: Human Resource Management (HRM) at level 1; Business Information Systems (BIS group $1 \& 2$ ); Corporate Administration and System (CAS) group at level 3; Final Year Project Group at Level 4 (Project Group); Academic Group from the Supplemental Instruction Progarmme (Academic Group). The questionnaires comprised fours parts. Part one involved a six-point Likert scale to assess satisfaction in college life. Findings indicate that students were not satisfied with personal development education provision. The second part of the survey enabled students to assess their own competencies. Students were invited to rank the top 10 competencies out of 21 competencies covering fundamental skills, personal management skills, teamwork skills, and skills extracted from the life skills module syllabus offered at the pilot institution. The 18 key competencies were identified as follows: 
Table 2: Students' perceptions of key competencies

\begin{tabular}{|c|c|c|c|c|c|c|c|c|}
\hline Course/Group & $\begin{array}{l}\text { Huma } \\
\mathrm{n} \\
\text { Resou }\end{array}$ & $\begin{array}{l}\text { Busi } \\
\text { ness } \\
\text { Infor }\end{array}$ & $\begin{array}{l}\text { Busine } \\
\text { ss } \\
\text { Inform } \\
\end{array}$ & $\begin{array}{l}\text { Corpor } \\
\text { ate } \\
\text { Admin }\end{array}$ & $\begin{array}{l}\text { Project } \\
\text { Group } \\
\text { Level }\end{array}$ & $\begin{array}{l}\text { Academ } \\
\text { ic } \\
\text { Level } 3\end{array}$ & $\begin{array}{l}\text { Leaders } \\
\text { hip } \\
\text { Level } 3\end{array}$ & $\begin{array}{l}\text { Total no. } \\
\text { in Group } \\
\text { (Maximu }\end{array}$ \\
\hline $\begin{array}{l}\text { 1.Communication } \\
\text { skills }\end{array}$ & 1 & 1 & 1 & 1 & 2 & 2 & 2 & 7 \\
\hline $\begin{array}{l}\text { 2. Managing } \\
\text { information }\end{array}$ & 5 & & & 4 & 6 & & & 3 \\
\hline 3. Using numbers & & & & & & & & $\mathbf{0}$ \\
\hline $\begin{array}{l}\text { 4. Creative } \\
\text { thinking }\end{array}$ & & & 7 & 6 & 7 & & 1 & 4 \\
\hline 5. Problem solving & 3 & 2 & 6 & 3 & 1 & 2 & 3 & 7 \\
\hline 6. Positive attitude & 5 & & 6 & 3 & & & & 3 \\
\hline $\begin{array}{l}\text { 7. Positive } \\
\text { behaviours }\end{array}$ & 5 & & & & 7 & & 5 & 3 \\
\hline 8. Responsibility & 4 & 2 & & 7 & 7 & 1 & 4 & 6 \\
\hline $\begin{array}{l}\text { 9. Continuous } \\
\text { learning }\end{array}$ & 5 & & & & & 3 & & 2 \\
\hline $\begin{array}{l}\text { 10. Working } \\
\text { safely }\end{array}$ & 5 & 3 & & & & & & 2 \\
\hline $\begin{array}{l}\text { 11. Work with } \\
\text { others }\end{array}$ & & 1 & 4 & 3 & 4 & 4 & 1 & 6 \\
\hline $\begin{array}{l}\text { 12. Participating in } \\
\text { projects and tasks }\end{array}$ & & & & & & & & $\mathbf{0}$ \\
\hline $\begin{array}{l}\text { 13. Interpersonal } \\
\text { skills }\end{array}$ & 3 & & & & 7 & 3 & & 3 \\
\hline 14. Social skills & & 2 & 5 & 5 & & 4 & & 4 \\
\hline $\begin{array}{l}\text { 15. Language } \\
\text { proficiency } \\
\text { - Cantonese } \\
\text { - English } \\
\text { - Putonghua }\end{array}$ & 2 & $\begin{array}{l}2 \\
3\end{array}$ & $\begin{array}{l}5 \\
8\end{array}$ & 2 & 5 & $\begin{array}{l}2 \\
4\end{array}$ & 5 & $\begin{array}{l}\mathbf{0} \\
\mathbf{7} \\
\mathbf{3}\end{array}$ \\
\hline $\begin{array}{l}\text { 16. Self } \\
\text { improvement }\end{array}$ & & & 3 & & & 4 & 4 & 3 \\
\hline $\begin{array}{l}\text { 17. Time } \\
\text { management }\end{array}$ & & 2 & 2 & 7 & & 1 & 4 & 5 \\
\hline $\begin{array}{l}\text { 18. Presentation } \\
\text { skills }\end{array}$ & & 3 & & 4 & & & 5 & 3 \\
\hline 19. Survival skills & & & & & & & & $\mathbf{0}$ \\
\hline 20. Handling stress & & 3 & & & 3 & 4 & & 3 \\
\hline $\begin{array}{l}\text { 21. Implementing } \\
\text { change }\end{array}$ & & & & & & & & $\mathbf{0}$ \\
\hline
\end{tabular}


Numbers across the row generate indication of group preferences against a particular competency. Results indicated that using number (item 3), participating in projects and tasks (item 12), language proficiency - Cantonese (item 15), survival skills (item 19) and implementing change (item 21) garnered no responses. All groups believed that communication skills (item 1), problem solving (item 5) and English proficiency (item 15) constituted the top 3 most important competencies from a student perspective.

Students were then asked to rank their top three methods that could be used in the Personal Development Programme (PDP). Across the seven groups, thirteen different training methods were suggested, as shown in Table 3. Frequency was calculated using the preference indicator (i.e. $\mathrm{f} / \mathrm{N}$ ) with the equation of frequencies (f) divided by number of responses $(\mathrm{N})$. The results were then ranked to provide an insight into students' preferred training methods. The results were as follows:

Table 3: Student choices of training methods in the PDP

\begin{tabular}{|l|l|l|l|l|l|l|l|l|}
\hline Course & $\begin{array}{l}\text { HR } \\
\text { M } \\
\text { Leve } \\
11\end{array}$ & $\begin{array}{l}\text { BIS } \\
\text { Level 2 } \\
\text { (Gp 1) }\end{array}$ & $\begin{array}{l}\text { BIS } \\
\text { Level 2 } \\
\text { (Gp 2) }\end{array}$ & $\begin{array}{l}\text { CAS } \\
\text { Leve } \\
13\end{array}$ & $\begin{array}{l}\text { Proje } \\
\text { ct } \\
\text { Grou } \\
\text { p } \\
\text { Level } \\
4\end{array}$ & $\begin{array}{l}\text { Acade } \\
\text { mic } \\
\text { Level } \\
3\end{array}$ & $\begin{array}{l}\text { Leader } \\
\text { ship } \\
\text { Level 3 }\end{array}$ & $\begin{array}{l}\text { Freque } \\
\text { ncy }\end{array}$ \\
\hline 1. Traditional lecturing & & & & & & & & $\mathbf{0}$ \\
\hline 2. Small group tutoring & 3 & & 1 & 3 & & & 1 & $\mathbf{4}$ \\
\hline $\begin{array}{l}\text { 3. Self-learning with } \\
\text { independent learning pack }\end{array}$ & & & & & & & & $\mathbf{0}$ \\
\hline $\begin{array}{l}\text { 4. Summer training } \\
\text { workshops }\end{array}$ & & & & 2 & 2 & & & $\mathbf{2}$ \\
\hline
\end{tabular}




\begin{tabular}{|l|l|l|l|l|l|l|l|l|}
\hline & $\begin{array}{l}\text { HR } \\
\text { Meve } \\
\text { Training Methods }\end{array}$ & $\begin{array}{l}\text { BIS } \\
\text { Level 2 } \\
\text { (Gp 1) }\end{array}$ & $\begin{array}{l}\text { BIS } \\
\text { Level 2 } \\
\text { (Gp 2) }\end{array}$ & $\begin{array}{l}\text { CAS } \\
\text { Leve } \\
13\end{array}$ & $\begin{array}{l}\text { Proje } \\
\text { ct } \\
\text { Grou } \\
\text { p } \\
\text { Level } \\
4\end{array}$ & $\begin{array}{l}\text { Acade } \\
\text { mic } \\
\text { Level } \\
3\end{array}$ & $\begin{array}{l}\text { Leader } \\
\text { ship } \\
\text { Level 3 }\end{array}$ & $\begin{array}{l}\text { Freque } \\
\text { ncy }\end{array}$ \\
\hline $\begin{array}{l}\text { 5. Action learning } \\
\text { (work-related projects). }\end{array}$ & & 1 & 1 & 1 & 1 & 1 & 2 & $\mathbf{6}$ \\
\hline $\begin{array}{l}\text { 6. Peer learning (Peer } \\
\text { Mentorship Programme) }\end{array}$ & & & & & & & & $\mathbf{0}$ \\
\hline 7. E-learning platform & & 2 & & & & & & $\mathbf{1}$ \\
\hline $\begin{array}{l}\text { 8. Learning with tutor and } \\
\text { buddies (e.g. Supplemental } \\
\text { Instruction Programme). }\end{array}$ & & & 2 & & & 1 & 3 & $\mathbf{3}$ \\
\hline $\begin{array}{l}\text { 9. Learning with same } \\
\text { counselor assigned for 4 } \\
\text { years }\end{array}$ & & & & & & 1 & & $\mathbf{1}$ \\
\hline $\begin{array}{l}\text { 10. Individual tutored } \\
\text { learning with the same tutor } \\
\text { for 4 years }\end{array}$ & 2 & & 2 & & & & & $\mathbf{2}$ \\
\hline 11. Distance learning & & & & & & & & $\mathbf{0}$ \\
\hline 12. Project work & 1 & 3 & & & 3 & & & $\mathbf{3}$ \\
\hline 13. Networking activities & & & & & & 1 & 3 & $\mathbf{2}$ \\
\hline
\end{tabular}

Students indicated that action learning (item 5, 6 votes), small group tutoring (item 2, 4 votes), learning support (item 8, 3 votes) and project learning (item 12, 3 votes) represented their preferred training methods to deliver personal development. In addition, students were invited to choose their preferred learning methods in the Personal Development Programme. A total of 127 out of 134 students (95\%) support the development of a programme to identify their learning needs. Students were asked to select their preferred structure as follows: 
Table 4: Students' views on the Structure of a Personal Development Programme

\begin{tabular}{|c|c|c|c|c|c|c|c|c|}
\hline & $\begin{array}{l}\text { HRM } \\
\text { Level } \\
1\end{array}$ & $\begin{array}{l}\text { BIS } \\
\text { Level } 2 \\
\text { (Gp 1) }\end{array}$ & $\begin{array}{l}\text { BIS } \\
\text { Level } \\
2(\text { Gp 1) }\end{array}$ & $\begin{array}{l}\text { CAS } \\
\text { Level } \\
3\end{array}$ & $\begin{array}{l}\text { Project } \\
\text { Group } \\
\text { Level } 4\end{array}$ & $\begin{array}{l}\text { Acade } \\
\text { mic } \\
\text { Level } 3\end{array}$ & $\begin{array}{l}\text { Leaders } \\
\text { hip } \\
\text { Level } 3\end{array}$ & $\begin{array}{l}\text { Averag } \\
\text { e }\end{array}$ \\
\hline $\begin{array}{l}\text { A. Type: } \\
\text { - Workshop } \\
\text { - Informal } \\
\text { Gathering }\end{array}$ & $\begin{array}{l}65 \% \\
35 \%\end{array}$ & $\begin{array}{l}95 \% \\
5 \%\end{array}$ & $\begin{array}{l}55 \% \\
45 \%\end{array}$ & $\begin{array}{l}86 \% \\
14 \%\end{array}$ & $\begin{array}{l}88 \% \\
12 \%\end{array}$ & $\begin{array}{l}67 \% \\
33 \%\end{array}$ & $\begin{array}{l}65 \% \\
35 \%\end{array}$ & $\begin{array}{l}75 \% \\
25 \%\end{array}$ \\
\hline $\begin{array}{l}\text { B. Duration: } \\
\text { - } 6 \text { months } \\
\text { programme } \\
\text { - } 1 \text { year } \\
\text { programme } \\
\text { - } 2 \text { year } \\
\text { programme } \\
\text { - Other ( } 3 \\
\text { months) }\end{array}$ & $\begin{array}{l}44 \% \\
44 \% \\
12 \% \\
0 \%\end{array}$ & $\begin{array}{l}55 \% \\
35 \% \\
10 \% \\
0 \%\end{array}$ & $\begin{array}{l}26 \% \\
47 \% \\
16 \% \\
11 \%\end{array}$ & $\begin{array}{l}55 \% \\
23 \% \\
13 \% \\
9 \%\end{array}$ & $\begin{array}{l}47 \% \\
53 \% \\
0 \% \\
0 \%\end{array}$ & $\begin{array}{l}33 \% \\
50 \% \\
17 \% \\
0 \%\end{array}$ & $\begin{array}{l}35 \% \\
53 \% \\
6 \% \\
6 \%\end{array}$ & $\begin{array}{l}42 \% \\
44 \% \\
11 \% \\
3 \%\end{array}$ \\
\hline $\begin{array}{l}\text { C. Frequency of } \\
\text { meeting: } \\
\text { - Once per month } \\
\text { - Two times per } \\
\text { quarter } \\
\text { - Twice a year } \\
\text { - Others }\end{array}$ & $\begin{array}{l}44 \% \\
39 \% \\
17 \% \\
0 \%\end{array}$ & $\begin{array}{l}30 \% \\
50 \% \\
20 \% \\
0 \%\end{array}$ & $\begin{array}{l}33 \% \\
56 \% \\
11 \% \\
0 \%\end{array}$ & $\begin{array}{l}54 \% \\
23 \% \\
23 \% \\
0 \%\end{array}$ & $\begin{array}{l}73 \% \\
13 \% \\
7 \% \\
7 \%\end{array}$ & $\begin{array}{l}50 \% \\
50 \% \\
0 \% \\
0 \%\end{array}$ & $\begin{array}{l}71 \% \\
23 \% \\
0 \% \\
6 \%\end{array}$ & $\begin{array}{l}51 \% \\
36 \% \\
11 \% \\
2 \%\end{array}$ \\
\hline $\begin{array}{l}\text { D. Days of Week: } \\
\text { - During } \\
\text { weekdays } \\
\text { - During } \\
\text { weekends- }\end{array}$ & $\begin{array}{l}64 \% \\
36 \%\end{array}$ & $\begin{array}{l}50 \% \\
50 \%\end{array}$ & $\begin{array}{l}71 \% \\
29 \%\end{array}$ & $\begin{array}{l}62 \% \\
38 \%\end{array}$ & $\begin{array}{l}80 \% \\
20 \%\end{array}$ & $\begin{array}{l}83 \% \\
17 \%\end{array}$ & $\begin{array}{l}81 \% \\
19 \%\end{array}$ & $\begin{array}{l}\mathbf{7 0 \%} \\
30 \%\end{array}$ \\
\hline $\begin{array}{l}\text { E. Meeting Time: } \\
\text { - During school } \\
\text { hours } \\
\text { - After school } \\
\text { hours } \\
\text { - Combination of } \\
\text { the above }\end{array}$ & $\begin{array}{l}61 \% \\
35 \% \\
4 \%\end{array}$ & $\begin{array}{l}47 \% \\
47 \% \\
6 \%\end{array}$ & $\begin{array}{l}28 \% \\
44 \% \\
28 \%\end{array}$ & $\begin{array}{l}44 \% \\
26 \% \\
30 \%\end{array}$ & $\begin{array}{l}33 \% \\
33 \% \\
34 \%\end{array}$ & $\begin{array}{l}80 \% \\
20 \% \\
0 \%\end{array}$ & $\begin{array}{l}64 \% \\
12 \% \\
24 \%\end{array}$ & $\begin{array}{l}51 \% \\
31 \% \\
18 \%\end{array}$ \\
\hline $\begin{array}{l}\text { F. Tutor / Person } \\
\text { in charge: } \\
\text { - Academic staffs } \\
\text { - Student } \\
\text { Development } \\
\text { Officer } \\
\text { - Professional } \\
\text { Counsellor } \\
\text { assigned by the }\end{array}$ & $\begin{array}{l}17 \% \\
39 \% \\
22 \% \\
22 \% \\
0 \%\end{array}$ & $\begin{array}{l}25 \% \\
35 \% \\
15 \% \\
\\
25 \% \\
0 \%\end{array}$ & $\begin{array}{l}20 \% \\
35 \% \\
30 \% \\
15 \% \\
0 \%\end{array}$ & $\begin{array}{l}28 \% \\
40 \% \\
16 \% \\
16 \% \\
0 \%\end{array}$ & $\begin{array}{l}20 \% \\
10 \% \\
35 \% \\
25 \% \\
10 \%\end{array}$ & $\begin{array}{l}29 \% \\
14 \% \\
14 \% \\
43 \% \\
0 \%\end{array}$ & $\begin{array}{l}22 \% \\
22 \% \\
28 \% \\
17 \% \\
11 \%\end{array}$ & $\begin{array}{l}23 \% \\
28 \% \\
23 \% \\
\\
23 \% \\
3 \%\end{array}$ \\
\hline
\end{tabular}




\section{department \\ - Professional \\ Counsellor \\ assigned by the \\ SDO \\ - Other Institute \\ or Mentor}

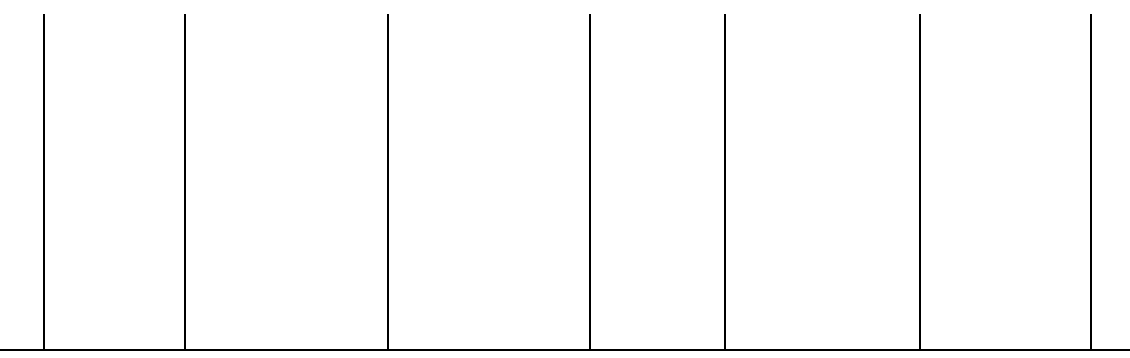

According to an analysis of the data in Table 4, students themselves suggested the future shape or structure of the PDP by completing the questionnaire with choices as listed in Table 4. Open-end questions were used so students could express their views if necessary. A majority of students suggested that the programme should be organised in the form of workshops, and certificates were preferred to recognise student learning and achievement (A. Type, 75\%). Students suggested that the course should last one year (B. Duration, 44\%) and that there should be monthly supervisory meetings (C. Frequency of meeting, 51\%). Meeting should be conducted during weekdays (D. Days of Week, 70\%) and during school time (E. Meeting Time, 51\%). The department-in-charge should be the Student Development Office (F. Tutor/Person in charge, 28\%).

In summary, students are aware of their needs and the demand of the workplace. Findings also indicate that many students do not have aspirations in life and life balance. The structure of the programme was also explored: a one year programme was suggested, incorporating workshops and certificates to recognize students' learning and achievement. Students' perspective of top three most competencies: communication skills, problem solving and English proficiency. They indicated their preferred training methods: soft skills training workshop and the experiential learning model emerged as preferred choices.

\section{Views of educators}

Firstly, educators were invited to comment on the existing personal development system. Six out of eight informants noted that students took formal modules to deliver personal education. Some further activities also explored in interviews included the Enhancement programme offered by Student Development Office, the China Business Studies module, and other activities such as cross-border visits. The effectiveness of the existing programme was also discussed. Only two educators agreed with the survey findings on students' key competencies (as illustrated in Table 2). A Principal Lecturer involved in plans for a new personal development programme said that such a programme was a possible method to help students develop competencies and there should also be a focus on developing good attitudes:

The programme should not only focus on competency training, but also on helping students develop as an individual. Recognition by the employer is not an important issue, but it is most important that we train up our students to have a good attitude in learning and working. Once a good attitude is developed, students can be trained and develop competencies to contribute to workplace and the community. Lastly, I would like to point out that the PDP should be based on individual needs and aim to develop personal identity. 
These comments were also supported by staff from the Student Development Office who emphasised that the programme should focus on developing 'quality'.

Three out of eight educators noted that certain skills might be difficult to incorporate in the formal curriculum, such as creative thinking, spoken English, and responsibility. There was agreement that informal learning was also important to develop skills. The findings show that a variety of training methods should be developed. A senior project officer and a training consultant provided further insights into competency-based training. They suggested that this method should be adopted in classroom learning and co-curricular activities. However, educators should understand that competencies must be clearly addressed to help students through learning. Performance indicators must be clear and transparent, and clearly linked to activities, where possible. A possible model is adapted from Murdock and Scutt's framework (2003, p.xxix) and involves 11 behavioral indicators to form a personal competency model (PCM) for business courses as illustrated in Table 1. As well as the PCM framework, the learning model should also integrate the pilot institution employability skills framework which covers three areas: fundamental skills (communication, managing information, numeracy, and problem solving); personal management skills (positive attitudes and behaviours, responsibility, adaptability, continuous learning, work safety); and teamwork skills (working with others and participating in projects and tasks). It is designed as a background personal competency framework for vocational students to draw learners' attention in competency development and help learners develop the right attitude to learning.

In summary, personal development is implemented formally in modules and informally through participation in extracurricular activities. Evidence here shows that the existing programme is too generalised and does not focus on personal needs. The majority of respondents say that training does not incorporate all competencies in the formal curriculum. Regarding pedagogy and curricula, it was agreed that informal learning is important in the development of skills. The possible model of personal competency model (PCM) can be adopted in teaching and learning so as to draw learners' attention in competency development and help learners develop the right attitude to learning.

\section{Views of human resource practitioners}

Firstly, recruitment was discussed. Prospective employers considered knowledge and competencies (including technical skills and soft skills) equally important overall. They also commented that students need all knowledge, skills and competencies to succeed in the modern job market. Through personal interviews with respondents, six interviewees identified 21 competencies as follows: 
Table 5: Comparison of the competency requirements for college and at workplace

\begin{tabular}{|l|l|l|}
\hline & Competency required at College level & $\begin{array}{l}\text { Competency required in selection (from } \\
\text { employers' perspective) }\end{array}$ \\
\hline 1 & Communication skills & Communication \\
\hline 2 & Managing information & Customer focus \\
\hline 3 & Using numbers & Business understanding \\
\hline 4 & Creative thinking & Personal effectiveness \\
\hline 5 & Problem solving & Creativity \\
\hline 6 & Positive attitude & Service mindset \\
\hline 7 & Positive behaviours & Working experience \\
\hline 8 & Responsibility & Language proficiency \\
\hline 9 & Learn continuously & Outgoing and friendly \\
\hline 10 & Work safely & Analytical power \\
\hline
\end{tabular}

\begin{tabular}{|l|l|l|}
\hline & Competency required at College level & $\begin{array}{l}\text { Competency required in selection (from } \\
\text { employers' perspective) }\end{array}$ \\
\hline 11 & Work with others & Interpersonal skills \\
\hline 12 & Participate in projects and tasks & Good team spirit \\
\hline 13 & Interpersonal skills & Knowledge \\
\hline 14 & Social skills & Independence \\
\hline 15 & Language proficiency & Professionalism \\
\hline 16 & Self improvement & Proactively \\
\hline 17 & Time management & Willingness to learn \\
\hline 18 & Presentation skills & Networking \\
\hline 19 & Survival skills & Leadership \\
\hline 20 & Handling stress & Problem solving \\
\hline 21 & Implementing change & Negotiation \\
\hline
\end{tabular}

Through detailed examination of the table above, we can see that only seven competencies are in common: communication skills, creativity, language proficiency, interpersonal skills, team spirit, willingness to learn, and problem solving. This suggests that competency levels at college are not sufficiently in line with employers' expectations. Educational institutions should review their programmes to narrow this gap.

In terms of training and development, one respondent suggested that experiential learning was one way to encourage students to expand their knowledge:

Skills can develop through experiential learning. As a professional human resource manager, I encourage staff to experience different situations through job rotation. By doing so, staff can familiarise themselves with frontline operations through hands on experience. Importantly, staff members not only learn about business in the most effective way, but also improve personal effectiveness and learn initiatively. 
Teaching and learning methods were also explored through personal interviews. Project work, competency-based learning, task-based learning and action learning were discussed by three experts as follows:

Human Resource Manager: Your college could adopt project work in teaching and learning. This kind of learning is not just one-way, but includes, for example, role-playing exercises.

Human Resource Officer: In a classroom setting, communication skills, English speaking and working with others can reinforce project work. A lot of work can take place in groups and students should be made aware of performance indicators. Outside the classroom, extracurricular activities centered on task-based learning encourage responsibility and positive attitudes.

Human Capital Management Officer: I also believe adopting action and project work in teaching and learning are good methods to help students develop. It would also be beneficial if these activities are linked with the businesses. In addition, there should be a good variety of methods: different training workshop, placements and competition.

Learning strategies were also emphasised. A Human Capital Management Officer suggested that students should devise, with staff, their own self-development plans, that reflecting learned skills and self-assessed needs.

Regarding the structure of the PDP programme, five out of six respondents agreed with the findings of the student survey. Also, the PDP as a lifetime programme was explored:

The PDP can work as a lifetime programme. At the Chartered Institute of Personnel and Development (CIPD), learners are required to develop their conduct individually through self-assessment in order to discover their training needs.

While students and educators strongly supported a formal personal development programme, employers argued that structure was not the crucial factor in successful personal development education. They also suggested that there was no single method or 'one size fits all' approach to personal development. They concern the design of a programme relevant to students and developing quality. The focus should be on developing students learning attitudes, nurturing independence and proactive learning. They also noted the added value of self-development through active participation in personal development activities: these are powerful learning techniques.

In summary, a wide variety of staff training methods was suggested to enhance skills, such as experiential learning. These methods can be delivered in an unstructured format. It was concluded that no single training method can inculcate all competencies. Teaching strategies include competency-based training, role-playing, action learning, and project work. It was also recommended that learning be based on personal effort, including 
self-assessment and proactive learning methods. The Chartered Institute of Personnel and Development learning model was recommended. Recognition of the programme by employers was not seen as the most pressing concern, nor was it seen as crucial in judging the success or not of the programme. The prime concern is the design of a programme relevant to students, and developing quality. Last but not the least, half of respondents agreed that a certificate should be presented to students, recognising their achievement in co-curricular participatory activities.

\section{IMPLICATIONS FOR TEACHING AND LEARNING APPROACHES}

Through the different stages of data collection, personal development opportunities to cope with change were discussed. Although different teaching strategies are adopted in teaching and learning, evidence suggests that improvement is needed in terms of contact hours, pedagogy with the programme design relevant to students and the development of market-driven courses to encourage creative thinking, problem solving, proactively and self-confidence in students. The findings indicate that students are aware of their needs and the demands of workplace. Students also suggested the future shape of the PDP. Moreover, the findings indicate that the majority of students do not have an aspiration in life, and that life balance and quality of life education should be integrated into the curriculum to develop awareness of broader life issues. Educators agreed on the need to review the existing personal development system and that competency-based training workshops should be offered to develop soft skills to support personal development. Due to the course duration is shorted to two years for completion at Higher Diploma level, there is insufficient time to deliver the skills that employers require. It is therefore necessary to develop co-curricular activities to improve personal and career development. In this regard, all activities (formal and informal) need to contribute to active learning through self-development and reflection. The following suggested workshops emerged from educators' comments and authors' teaching experience:

Table 6: Co-curricular activities / Active Learning Model to be integrated in curriculum

\begin{tabular}{|l|l|}
\hline Attributes & $\begin{array}{l}\text { Example of co-curricular activities / Active Learning Model } \\
\text { in classroom learning }\end{array}$ \\
\hline 1. Team work & $\begin{array}{l}\text { Teambuilding workshop, leadership workshop, mentorship } \\
\text { scheme, collaborative learning, project work }\end{array}$ \\
\hline $\begin{array}{l}\text { 2. Career development and work } \\
\text { attitude }\end{array}$ & $\begin{array}{l}\text { Workplace Attachment Scheme, company visits, flexible } \\
\text { learning }\end{array}$ \\
\hline 3. Self confidence and EQ & Simulated interviews, EQ Workshop \\
\hline 4. Career and ethics & $\begin{array}{l}\text { ICAC Workshop, Book reading scheme, Voluntary work, } \\
\text { Action learning }\end{array}$ \\
\hline 5. Self, family, work and society & $\begin{array}{l}\text { Community projects, family education, company visits, } \\
\text { task-based learning, cross-border visits }\end{array}$ \\
\hline $\begin{array}{l}\text { 6. Improving learning and } \\
\text { performance }\end{array}$ & $\begin{array}{l}\text { Simulated performance appraisal workshops, Supplemental } \\
\text { Instruction Programme, competency based learning, learning } \\
\text { new skills }\end{array}$ \\
\hline 7. Communication & Peer Mentorship Programme, group learning, presentation \\
\hline
\end{tabular}




\begin{tabular}{|l|l|} 
8. Problem Solving & $\begin{array}{l}\text { Process restructuring workshop, workshop on crisis } \\
\text { management, managing change workshop, problem-based } \\
\text { learning }\end{array}$ \\
\hline 9. Life Balance & $\begin{array}{l}\text { Networking workshop, social skills workshop, music } \\
\text { appreciation party, Talk on spa / facial / physical exercise / } \\
\text { music to release stress, holiday experience sharing }\end{array}$ \\
\hline
\end{tabular}

Stakeholders suggest teaching guides, learning tools and the active learning model are necessary to support personal development through informal learning; these are new routes to successful learning and personal development. Learning tools, including Personal Needs Survey (Appendix A), Personal Competency Model (Appendix B), and a Personal Development Learning Plan (Appendix C \& D), have been developed for this study.

\section{Teaching guide}

As noted by human resource practitioners, there is no single method suitable for all competencies. Educators need to identify the suitable training method for a particular co-curricular activity or programme. Different active learning models can be adopted. Applicable models, derived from this study, include action learning, flexible learning, collaborative learning, project work, competency based learning, peer-assisted learning, self-regulated learning, problem-based learning and constructivism in learning. The following questions are guidelines at the planning stage:

What are students' current needs (personal, financial, psychosocial, and career)?

What kinds of programme (or modules, activity) do colleges offer to students?

What alternative activities can we offer if we can't satisfy the students' needs?

What kind of active learning model should be adopted?

How can students be helped to reflect upon what they learn?

How can students be encouraged to learn independently and through peers?

Where can the programme to take place?

Who will be in charge of the programme and who will assess student performance?

Educators have to consider all the questions listed above - especially those relating to the availability of human and physical resources. Educators need to select active learning that is most relevant to the particular unit, course, activity or programme. Stern and Huber (1997, p.19) argue that "in more active forms of learning, learners make their own time plan, they choose learning goals and activities they like, they test their progress, they take care of learning and understanding on their own, and they reflect on errors and successes." Learning goals should be formulated to support self-development and good learning attitudes.

\section{Curriculum plan}

In curriculum design, concepts, knowledge, skills, attitude and self-development should be integrated into each co-curricular activity. In order to identify students' needs, educators should conduct a needs survey to determine the most appropriate project, task or activity to use. The following is an example curriculum design: 
Table 7: Curriculum design (for co-curricular activities)

\begin{tabular}{|c|c|}
\hline Programme Title (Level) & $\begin{array}{l}\text { Informal Learning Programme (for Year Two or Level Three } \\
\text { students) }\end{array}$ \\
\hline Theme for the programme & To be a good coach to motivate learners' to learn effectively \\
\hline Hours involved & $\begin{array}{l}\text { Ten hours face to face consultation and ten hours informal } \\
\text { communication }\end{array}$ \\
\hline Programme aims & $\begin{array}{l}\text { 1. To help students become effective learners by enhancing } \\
\text { their learning skills and spurring motivation and interest in } \\
\text { their studies. } \\
\text { 2. To increase students' psychological health through personal } \\
\text { support. } \\
\text { 3. To develop a learning culture where student learn and grow } \\
\text { together. }\end{array}$ \\
\hline $\begin{array}{l}\text { Applicable active learning } \\
\text { models }\end{array}$ & Collaborative learning and action learning \\
\hline Assessments Tools & $\begin{array}{l}\text { Portfolio, reflective journal and personal development } \\
\text { learning plan }\end{array}$ \\
\hline $\begin{array}{l}\text { Co-curricular } \\
\text { Outcomes }\end{array}$ & Leadership skills and coaching skills \\
\hline Applicable professions & Social worker; Teacher; Counselor; Trainer \\
\hline
\end{tabular}

\section{Learning tools}

When planning a programme, it is important to understand student needs. A Personal Needs Survey (PNS) can be conducted. Stern and Huber (1997, p.75) note that "helping students become aware of their own role and possibilities in the learning process is the first step to increase students' responsibility and a way to reduce students' frustration." Through such a survey, students gain a deeper understanding of their needs, goals and take greater responsibility for their learning. Our target group - young people in their early twenties - may have a range of needs and concerns, such as personal issues, finance or career development. The four part form of Personal Needs Survey (Appendix A) is designed to identify students' needs, strengths and weakness (parts I-III). Part IV is completed by the advisor or educator after discussion with students and provides a suggested personal development plan. Once students understand their goals, they will make greater effort to complete the programme. As a result, concepts, knowledge, skills and a good learning attitude will bolster personal development. The needs survey can form the basis of a suitable programme design.

\section{A Practical Example}

The Supplemental Instruction (SI) programme improves learning using the input of senior students. Students participate as 'leaders' (to familiarise them with the consultancy 
profession) or as 'members' (to develop learning ability). Students form groups of four or five, each lead by a senior student. Formal and informal learning methods are used in SI. Formal training workshops such as "Peer-teaching", "Effective Teaching Skills", "Coaching skills", "Communication Skill" and "Effective Learning Strategies" are organised that leaders develop reflective learning, communication and coaching skills prior to their appointment as leaders. Leaders promote competency and members focus on ways to learn effectively. The Chartered Management Institute Personal Competency Model (PCM) is adopted in the SI Programme as illustrated in Appendix B. Participants use the PCM to identify and develop relevant behaviours and skills. Trainers or advisors design relevant co-curricular activities to focus on individual achievement and adopt criterion-referenced setting. Cotton (1995, p.142) argues:

In criterion-referenced testing, each individual is measured against a set of agreed standards, independent of other learners. There are strengths and weakness in the trend towards using achievement as a measure of learning. On the plus side, learners have a very clear picture of what they are able to do, so that positive strengths are quickly incorporated in the learner's self-image and may well increase individual self-esteem and motivation. Such constructive reassurance is helpful to the individual's pursuit of wisdom.

The SI programme provides SI leaders the opportunity to build skills, lead a discussion and develop more active involvement, with resources provided by SI co-ordinator and SI leaders, including relevant exercises such as business accounting quizzes and economics and business analysis to help SI members learn effectively. Regarding assessment, the following methods are used in personal development (especially in the SI programme) as follows:

\section{(1) Self-reflective journal}

Educators establish competency and behaviour indicators for each activity. Students assess themselves on the basis of these. A self-reflective journal can be used to the record tasks completed, and reflect on achievements in a systematic way. The following format is referenced from activity suggested by Elearn Ltd (2005, p.17) to be adopted in co-curricula activities as follows:

\begin{tabular}{|c|c|c|c|c|}
\hline $\begin{array}{c}\text { Key } \\
\text { dates }\end{array}$ & $\begin{array}{c}\text { The } \\
\text { experience/ } \\
\text { Work done: }\end{array}$ & $\begin{array}{c}\text { What have you learnt } \\
\text { from experience: }\end{array}$ & $\begin{array}{c}\text { What you will do as } \\
\text { a result of the } \\
\text { experience: }\end{array}$ & $\begin{array}{c}\text { When you will } \\
\text { review this / } \\
\text { Any further } \\
\text { action: }\end{array}$ \\
\hline
\end{tabular}

A self-reflective journal can be submitted at the end of the programme and integrated in the Personal Development Learning Plan (Appendix C, Part 1).

(2) Personal Development Learning Plan 
Students need to record progress in the Personal Development Learning Plan (PDLP) around the issues of reflecting back (what they have learnt), sharing experience (sharing knowledge and ideas), future career prospects (application of skills) and a Planned Personal Outcome Schedule (competencies and skills). In addition, the SI programme provides SI leaders the opportunity to lead a discussion with members and the issues of project proposal would be integrated in the PDLP (Appendix D, Part 1). The plan is adapted from the Chartered Institute of Personnel and Development plan. It can be used as an assessment tool to record learners' skills and knowledge developed through participatory co-curricular activities, and also can help to shape the programme for the next academic year. Students are seen as forward-looking, self-motivated people capable of change and progress and with the ability to assess their performance personally.

\section{(3) Portfolios}

Portfolios should be submitted at the end of programme. Students create portfolios to illustrate skills acquired and enhanced through the learning process. Students' strength and weakness are identified through self-reflection. Advisers provide support or guidance when appropriate. As suggested by Cobia and Henderson (2003, p.19), portfolio components can be adapted and include the following elements:

a) Prepare a reflective statement describing the motivation to join the co-curricular activity. Include a summary of interpersonal and intrapersonal strengths that enhance personal competency and development. Also, identify any limiting factors and describe how they will be overcome.

b) Reflect on and identify personal beliefs about the purposes of education. Describe the necessary action to take to achieve goals.

c) Reflect on how the skills learned through this programme can be applied in wider life.

These portfolios are used to assess the student competencies and learning progress. The use of portfolios helps develop a more flexible approach to assignment work. Portfolios can be used to demonstrate student knowledge or understanding, and also help them focus on goals. By reviewing the portfolio regularly, both teachers and students can evaluate progress and direction, and set new goals and objectives (Crackett 1998, p.9).

To sum up, this study discusses learning through co-curricular activities, appropriate assessment methods, programme design, and the integration of a competency based approach and active learning into co-curricular activities. As the study indicates, learning can take place outside formal courses, and therefore participatory co-curricular activities represent good learning opportunities. Active learning can maximize learners' learning experiences through peer support, learning sets, needs surveys, personal learning development plans, portfolios and self-reflective journals. 


\section{FUTURE DEVELOPMENT}

This study is a case study at one institution and much of the evidence is attitudinal and relates to the very particular context of Hong Kong. Contextual factors mean that recommendations in this study cannot simply be assumed to be relevant to other settings. Nonetheless, we content that much of this case study is likely to be relevant to other settings. In this study, various suggestions were explored to support personal development education at vocational level. Key recommendations are as follows:

\section{Flexible Personal Development Programme}

To determine a suitable programme, a needs assessment should be conducted to help outline the content of a plan. This also supports the development of knowledge, skills and attitudes through active participation. Once a survey is conducted, performance standards, competency and behaviour indicators should be clear in the programme content. If resources are available, an information platform should be developed to upload relevant information for learners to use themselves. Learners can use this resource flexibly, and at their own pace. Extra-curricular activities and self-development and other personal development activities can be integrated into the formal curriculum. A suitable programme, like the Supplemental Instruction programme, can achieve a dual purpose: counseling training for leaders, and effective learning for members.

\section{Yearly programme with a main theme}

As developed at the Hong Kong Institute of Human Resource Management, a yearly programme with a main theme can be developed. Students register with the programme on a voluntary basis and submit documents at the end of the year to demonstrate their continuous learning. These documents can include personal competency inventories, needs surveys, Personal Development Learning Plans, a reflective learning journal, and a portfolio.

\section{Active learning}

A wide range of activities, including action learning, project work, flexible learning, collaborative learning, constructive in learning, self-regulated learning, peer-assisted learning and experiential learning can be integrated in co-curricular activities to support the development of skills through active participation. Competency-based learning can also be integrated into co-curricular curriculum design. The active learning model and competency-based learning are not commonly adopted in the existing system. However, they should be developed in the new personal development system to support the development of social and interpersonal skills and other employability skills.

\section{Student awards}

One way to motivate students to participate in co-curricular activities, and encourage achievement, is to implement an awards system involving formal certification in the final year. This kind of recognition is real and reinforces students' motivation and confidence. Competency in the form of performance and behaviour indicators should be acknowledged and documented, and these can be used by prospective employers. 


\section{External support}

Outside resources are also important to support personal development education. Employers can participate in assessing students' performance and provide feedback on students' competency levels. All records should be kept in students' personal files. If possible, testimonial/reference letters should be issued by employers to recognise students' experiential learning during summer internships. Such extrinsic motivation can encourage student achievement, because an employer's reference is good for future job prospects. Nijhof and Brandsma (1999, p.11) also note that vocational education needs to be closely linked to employers, whilst at the same time preserving some autonomy. Employers can form business partnerships and advise providers on content and programme reviews.

\section{Learning environment}

Educators can create a good learning environment to support students intrinsically in their self-esteem, creating expectations to succeed, so students strive for success in study.

\section{Learning groups}

Group of 4-5 students can help students learn together. These groups develop trust and a good learning atmosphere, and maintain standards, thereby strengthen the learning process.

\section{Learning attitude and the individual}

'People factors' can affect learning. Students should develop such positive characteristics as noted by Gerson and Gerson (2006, p.40), good learning attitudes, perseverance and motivation. These characteristics of a rounded individual bolster lifelong learning. Lifelong learning augments personal development: it is a virtuous circle.

\section{Competency profile}

Specific competencies associated with a particular job must include relevant knowledge, skills (including technical and general skills) and attitude. Attitude is part of personal skills, and may seem obscure to students. Education institutions should educate students on the importance of personal skill to support lifelong learning.

\section{Teaching Guide}

Teaching guides, as suggested in discussion, should be designed for co-curricular activities and can include tools such as the needs survey and personal development learning plans. The needs survey focuses on student needs, strengths and weaknesses and also can help shape the design of programmes for students.

\section{Assessment Strategy}

A range of assessment tools can be adopted: reflective journals, peer evaluation, portfolios, objective tests, presentations, concept mapping and letters home. Educators can select the appropriate assessment methods for each scenario. Competency and behavioural standards should be made clear to students. In particular, reflective methods should be emphasised as this encourages good, proactive learning attitudes and participation. 


\section{Staff Professionalism}

Staff should have the skills to apply competency-based and active learning models, to implement best teaching practice relevant to their disciplines and modules, and also have a clear commitment to the education and training industry.

\section{An Active Learning Model for Informal Learning}

This study formulates new teaching and learning strategies for informal learning to support individual development. An active learning model to develop people should comprise of seven components: teaching strategies, a personal development programme, learning strategies, learning process, learning implementation, learning attitude and learning outcomes. The following diagram illustrates the relationships between the seven components of active learning model:

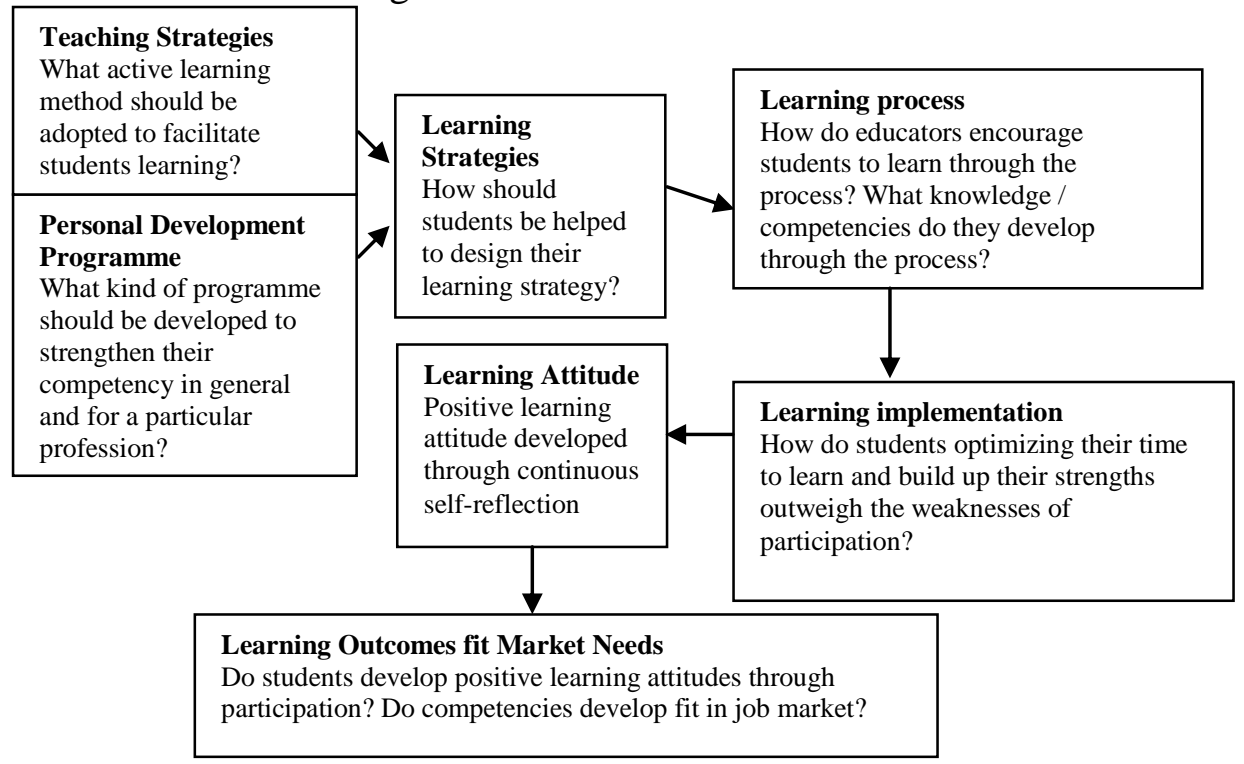

\section{Figure 2: Modern strategies to develop people}

\section{Stakeholders}

Developing positive learning attitudes to continuous learning is crucially important. Learning can take place both formally in class and informally. Stakeholders can enhance learning as follows:

a) Training providers

A positive learning environment and policies should be developed by providers to create more learning opportunities and broaden students' horizons through experiential learning. Institutional culture should change to embrace the active learning model. In addition, the institution should forge partnerships with other organisations such as commercial firms, education providers, youth organisations and social enterprises to expand opportunities for students. In addition, they should design an active learning model for informal learning to cope with new components of judging competency: knowledge, skills, learning attitudes and self-development, as follows: 
(1) Students' learning attitudes

-With mind and heart

-Learning to learn informally

- Learning to learn using own initiative

- A positive attitude

(2) Students' knowledge and skills

-Knowledge and skills are interrelated and both elements are important in securing good employment

-Skills should comprise of technical skills and soft skills depending on the post

(3) Students' self-development

-Students develop properly if they understand their own learning requirements and have career goals

b) Employers

Employers can support the education sector through business partnerships and by providing placements. In addition, they can contribute to student assessment, and provide feedback on student learning at the workplace which can be used to evaluate the effectiveness of co-curricular activities and workplace learning more generally.

c) Educators

Educators should be good curriculum designers. In addition, they should help students to identify needs and personal goals, as evidence indicates students are motivated by goal setting. Students should be positively encouraged to learn intrinsically and good attitudes should be reinforced. Once students adopt positive attitudes to learning, they will strive to achieve their academic and personal goals. However, a balance needs to be struck: over-praising can seem insincere and patronising, whilst absence of praise is discouraging. An active learning model can also be used to develop learning and positive attitudes. Pedler (1991, p.166) argues that the teachers are shifting from being 'teacher-experts' to 'learning facilitators'.

d) Learners

To be effective learners, people should develop the ability to learn continuously and understand their strengths and weaknesses through reflection. Learners should take responsibility to learn instead of totally relying on the curriculum provided by the institution. In addition, positive learning attitudes should be developed. Positive learning attitudes open up broad fields of knowledge and skill sets, and bolster lifelong learning.

All around the world, good knowledge and appropriate skills are important. However, the modern job market demands even more; good attitudes and continuous proactive lifelong learning are now the keys to success. However, the importance of vocational learning goes further than this as it is, linked to arguments about active citizenship and full self-actualisation. The kind of programme outlined here has the potential to nurture fully 
rounded individuals. However, in Hong Kong, and elsewhere, the success of such programmes requires active collaboration by all relevant stakeholders.

\section{FURTHER SUGGESTIONS}

As regards the design of a personal development curriculum, and successful informal learning methods, the following are basic suggestions and insights. These ideas should provide good support in the development of rounded individuals:

- Conduct a needs survey first to design a programme to fit learners' needs

- Develop a well structured personal development programme with a main theme in line with professional standards, helping familiarisation with a particular profession

- Identify clearly relevant personal behaviour and skills to be developed and used as illustrated in Appendix B

- Ensure professional standards in people skills correspond with employability skills as suggested in the section of "Implications for Teaching and Learning Approach"

- Use assessment tools to keep track of learners' progress to develop learners' reflective skills and proactive learning attitude in form of learning tools introduced in this chapter

- Include collaborative learning structures to encourage students to learn through peers and develop good self-image and self-esteem in groups

- Select correct active learning strategies or activities to reinforce students' awareness of self-development and self-assessment attitudes

- Continuous review of learning materials and active learning exercises throughout the course or programme. Educators can conduct review meetings when needed to understand learners' development of competencies. Use of evaluative rather than descriptive methods as suggested by the Chartered Institute of Personnel and Development (CIPD)

- Look for learning opportunities in class. Lectures can be mixed with active learning activities, learning and self-assessment in groups, and reflective learning approaches

- Look for out-of-class learning opportunities: adopt active learning strategies to augment personal development and recognise students' learning experience as long as students can provide evidence that competencies are enhanced through active participation

- Begin the active learning model at the start of term so that students have time to adapt to self-development learning methods; students can develop their own knowledge using continuous self-reflection to learn from concrete experiences, as shown in Kolb and Fry learning cycle illustrated in Figure 1

- Try to be flexible, fun and relevant to students' needs. Design training programmes that correspond to different competencies. The learning outcomes of informal learning should be more student-oriented and also in line with professional requirements and the job market 
By considering all the suggestions above, educators and training providers can be excited by outcomes. Student achievement may exceed expectations; there is more active student involvement in the learning process and students participate in their own learning experiences and strengths could be enhanced to become life-long learners. 


\section{REFERENCES}

Arter J. (2001). Scoring rubrics in the classroom: Using performance criteria for assessing and improving student performance. Thousand Oaks: Corwin.

Athanasou J. (2007). Evaluating Career Education and Guidance. Shannon Books: ACER Press.

Barnes R. (1999). Positive Teaching, Positive Learning. London and New York:

Routledge.

Chapman D. \& Adams D. (2002). The Quality of Education: Dimensions and Strategies. Manila, Philippines: Asian Development Bank; Comparative Education Research Centre; The University of Hong Kong.

Cobia D. C. and Henderson D. A. (2003) Developing an Effective and Accountable

School Counseling Programe. $2^{\text {nd }}$ Edition. Upper Saddle River: Pearson Education.

Cotton J. (1995). The theory of learners: an introduction. London: Kogan Page.

Crackett T. (1998). The Portfolio Journey: A Creative Guide to Keeping Student-

Managed Portfolios in the Classroom. Englewood, Colorado: Teacher Ideas Press.

Education Commission (2000). Learning for Life, Learning through Life. Reform Proposals for the Education System in Hong Kong. Hong Kong: Government of the Hong Kong Special Administrative Region of The People's Republic of China.

Education and Manpower Bureau (2004). Personal Growth Education, Revised 2004. Hong Kong: School Development Division.

Edwards R., Hanson A. and Raggatt P. (1996). Boundaries of Adult Learning: Adult Learners, Education and Training 1. Great Britain: Routledge.

Elearn Ltd. (2005). Management Extra. Managing Yourself. Oxford, U.K.: eLearn: Elsevier: Pergamon Flexible Learning.

Fletcher S. (2000). Competency-based assessment techniques. London: Kogan Page.

Gerson R. F. and Gerson R.G. (2006). Positive Performance Improvement. A New

Paradigm for Optimizing Your Workforce. Mountain View, California: Davies-Black. 
Guillaume A.M., Yopp R.H. \& Yopp H. K. (2007). 50 Strategies for active teaching. Engaging K-12 learners in the classroom. Upper Saddle River: Pearson Education.

Hofer B. K. \&Pintrich P.R. (2002). Personal epistemology: the psychology of beliefs about knowledge and knowing. Mahwan and London: Lawrence Erlbaum.

Infed.(no date) David a. kolb on experiential learning. Retrieved on 26 August, 2006, from http://www.infed.org/biblio/b-explrn.htm

Johns H. (1996). Personal Development in Counsellor Training. London: Cassell.

Joy-Matthews J., Megginson D. and Surtees M. (2004). Human Resource Development. London: Kogan Page.

Joyce B.R. \& Calhoun E.F.(1996). Creating learning experiences: The role of instructional theory and research. Alexandria, Virginia: Association for Supervision and Curriculum.

Kember D. (2008). Nurturing generic capabilities through a teaching and learning environment which provides practise in their use. Centre for Learning Enhancement And Research. The Chinese University of Hong Kong.

Leung A.S.M. (2008). The Effectiveness of Personal Development Opportunities at the Hong Kong Institute of Vocational Education (Tsing Yi). Unpublished EdD thesis: The University of Nottingham.

Leung A.S.M. and McGrath S. (2010). An Effective Learning Model to Support People Development: The Emerging Approach of the Hong Kong Institute for Vocational Education. Journal of International Education Studies. Canadian Center of Science and Education,Vol.2, No.4, 94-106.

Michael J.A. \& Modell H.I. (2003). Active Learning in Secondary and College Science Classrooms. A Working Model for Helping the Learner to Learn. Mahwah, New Jersey: Lawrence Erlbaum.

Miles D.H. (2003). The 30-Second Encyclopedia of Learning and Performance: A Trainer's Guide to Theory, Terminology, and Practice. New York: American Management Association.

Murdock A. \& Scutt C. (2003). Personal Effectiveness ( $3^{\text {rd }}$ edition). Oxford: Butterworth, Heinemann. 
Nifakis D. and Barlow L.(2007). Learning Through Peer Helping. Learning about Learning: Forum for Mills Learning Commons Partners. Available at: http://library.mcmaster.ca/mills/learningcommons/forum/nifakis_barlow.pdf (retrieved on 14 March 2008)

Nijhof W.J. \& Brandsma J. (1999). Bridging the Skills Gap between Work and Education. Dordrecht: Kluwer.

Noll Wm. J. (2009). Thinking sides: Clashing Views on Educational Issues, $15^{\text {th }}$ edition. New York: McGraw Hill.

Pedler M. (1991). Action Learning in Practice. London: Gower.

Silberman M.L. (1990). Active Learning. A Handbook of Techniques, Designs, Case Examples and Tips. New York: Lexington.

Sumerall S.W. and Lopez S.J. and Oehlert M.E. (2000).Competency-based education and training in psychology: a primer. Springfield, Illinois: Charles C Thomas.

Stern D. \& Huber G.L. (Eds.)(1997). Active Learning for Students and Teachers: Reports from Eight Countries. Frankfurt am Main: Peter Lang.

Stevenson J. (2003). Developing vocational expertise: principles and issues in vocational education. Crows Nest, N.S.W.: Allen \& Unwin.

Zimmerman B.J., Bonner S. \& Kovach R. (1996). Developing self-regulated learners: beyond achievement to self-efficacy. Washington, DC: American Psychological Association. 
Dr. Anita Sui Man Leung has worked for the Vocational Training Council in Hong Kong for twelve years. Her previous work on curriculum design helped secondary school teachers integrate business education into secondary school curricula. She is now exploring ways to formulate a new model for competency, informal learning, personal development and peer-assisted learning recognition scheme, which will provide new insights into improving personal education system within vocational training and at university level.

Correspondence regarding this chapter can be sent to: asmleung@ vtc.edu.hk 